\title{
Victim or Villain? Racial/ethnic Differences in News Portrayals of Individuals with Mental Illness Killed by Police
}

\author{
Emma Frankham, University of Wisconsin-Madison
}

orcid.org/0000-0001-7040-5941

\begin{abstract}
As a social problem, little is known about how individuals are portrayed in the news when race/ethnicity and mental illness intersect. This is important because of the ability of news to influence perceptions and policies about mental illness across race/ethnicity. This article examines how individuals with mental illness who were killed by police during 2015 and 2016 were portrayed in the news. Content analysis of 301 online news articles indicates that stereotypes associated with mental illness were differentially applied by race/ethnicity. Findings have implications for public attitudes about mental illness across race/ethnicity.
\end{abstract}

Keywords: news; mental illness; race/ethnicity; police

A revised version of this working paper is forthcoming in The Sociological Quarterly. This paper is not the copy of record and does not exactly replicate the final, authoritative version of the article. Please do not copy or cite without permission of the author. 
Police misconduct has been elevated to an unprecedented "new visibility" due to smartphone technology (Goldsmith 2010), with much news coverage being generated around these incidents, particularly fatal shootings by police. Both race/ethnicity and the role of mental illness in these fatalities have become a crucial part of the debate over both the legality and the morality of these incidents. Regarding race/ethnicity, publicized cases of fatal police shootings have generated momentum around concerns regarding police interactions with persons of color that has not been seen since the widespread civil unrest that followed the 1992 beating of Rodney King. Regarding mental illness, it has been observed that individuals with mental illness account for approximately a quarter of fatal police shootings and are likely overrepresented compared to those without mental illness in terms of police violence (The Washington Post 2017). In response, mental health advocacy organizations have expressed concerns about police interactions with persons with mental illness.

News reports about individuals with mental illness killed by police may be regarded as a crime story. These incidents involve a police officer, or officers, killing a civilian. Typically, these homicides are not considered a crime unless the police officer is found to be at least negligent. However, readers may still regard this news story as crime news because they involve both the police, who the public often associates with crime, and the death of an individual. Furthermore, many of the individuals with mental illness killed by police committed a crime, or threatened to commit a crime, before being killed. Often, this was in the form of threatening or violent behavior. Therefore, depending on the specific case, police officers or the individual killed by police may be regarded as having behaved criminally.

As a social problem, little is known about how individuals are portrayed in the 
news when race/ethnicity and mental illness intersect. This is important because the news has agenda-setting power (McCombs 1997; McCombs and Shaw 1993; Paletz and Entman 1981; Scheufele 2000), and the news may also influence how individuals view events and identify issues worthy of policy-intervention (Cavender and Mulcahy 1998). In particular, the news may influence attitudes and prejudices about mental illness by race/ethnicity. News coverage about the fatal shootings of civilians by police will be used in this article as a case study for examining how race/ethnicity and mental illness intersect to reinforce prejudices about race/ethnicity and stereotypes about mental illness. Through a content analysis examining how individuals were portrayed in news coverage of fatal police shootings, this article adds to the current literature by demonstrating that stereotypes associated with mental illness are differentially applied by race/ethnicity in the news.

\section{Literature review}

Crenshaw (1989) argued that researchers should adopt an "intersectional" approach to the study of phenomena where categories of social identity intersect and interact to reinforce each other in a matrix of cultural domination. In particular, she argued that there is a "tendency to treat race and gender as mutually exclusive categories of experience and analysis... any analysis that does not take intersectionality into account cannot sufficiently address the particular manner in which Black women are subordinated" (p. 139-140). While much research has been done at the intersection of race and gender since Crenshaw first articulated her ideas, Crenshaw herself has argued that "intersectionality can't wait" regarding less attention being paid to Black women being killed by police than Black men (Crenshaw, 2015). Furthermore, other areas of 
research continue to suffer by not considering how different aspects of identity may intersect and reinforce each other. In particular, there is a tendency for research to examine either how race/ethnicity may be a factor in the portrayal of individuals in news reports, or how individuals with mental illness may be portrayed. However, little is known about how individuals who have identities at the intersection of mental illness and race/ethnicity are portrayed in the news. When both race/ethnicity and mental illness intersect as part of an individual's identity, prejudice toward both persons of color as well as stigma toward those with mental illness may interact and reinforce each other.

By adopting an intersectional approach to the analysis of news portrayals of persons with mental illness, more may be revealed than would be if examining race/ethnicity and mental illness as mutually exclusive categories. These categories may interact in different ways for Whites, African-Americans, or Hispanics killed by police. Below, some of the general characteristics of crime news will be discussed, as well as research on the portrayal of race/ethnicity and mental illness in both crime news as well as news more broadly.

\section{Characteristics of crime news}

The agenda-setting power of the media has frequently been the focus of research since the 1980s (McCombs 1997; McCombs and Shaw 1993; Paletz and Entman 1981; Scheufele 2000). It has been argued that "in setting the public agenda, the news media influence the salience or prominence of that small number of issues that come to command public attention" (McCombs 1997:433). News frames that are used in coverage of events simultaneously "reflect, reinforce, and shape" how individuals view events and identify issues worthy of policy-intervention (Cavender and Mulcahy 
1998:698).

News reports about crimes often use particular frames. Cavender and Mulcahy (1998) proposed that crime news frames often include both the "attribution of responsibility" as well as the "individualization of responsibility" (p. 699). Individuals are commonly depicted as villains in crime news, and are often "blamed and denounced" (Cavender and Mulcahy 1998:700). This public denouncement may resemble what Garfinkel (1956) described as a "status degregadation ceremony" in which "the public identity of an actor is transformed into something looked on as lower in the local scheme of social types" (p. 420). As well as the depiction of individuals as villains, the individualization of responsibility may produce heroes or victims (Cavender and Mulcahy 1998). Overall, this body of research suggests that crime news reports contain frames depicting individuals as victims or villains in attributions of individual responsibility. In the context of this article, how race/ethnicity and mental illness intersect may influence whether an individual is depicted as a 'victim' or a 'villain,' as well as the types of frames that are used to portray them as such.

\section{Race/ethnicity and mental illness in the news}

There has been a plethora of research examining how racial and ethnic minorities have been portrayed in crime news and several research areas have emerged. First, the extent to which news frames reflect differences in crime participation by race/ethnicity has been examined. For example, some research has indicated that racial/ethnic differences in portrayals of individuals in crime news reflects racial/ethnic differences in the "real" share of arrests and offending (Chiricos and Eschholz 2002). Regarding the portrayals of individuals as victims of crime in the news, research has indicated that Hispanics are underrepresented, African-Americans are accurately represented, and 
Whites are overrepresented (Dixon and Linz 2000a; Dixon 2015).

Second, the content of news portrayals by race/ethnicity and whether these portrayals involve racial/ethnic stereotypes has been examined. For example, news frames may be used to convey the belief that "criminals are nonwhite" (Iyengar, Simon, and Wright 1996:6) and African-Americans may be portrayed as being particularly threatening and dangerous (Dixon and Maddox 2006; Dixon 2007; Entman 1992). Specifically regarding the portrayal of individuals fatally shot by police, researchers have highlighted how the most well-known individuals have at times been portrayed negatively (Dukes and Gaither 2017). For example, 18-year-old, unarmed Black teenager Michael Brown who was killed in 2014 was described as "no angel" and a "thug" by the media, and Eric Garner, a 43-year-old unarmed Black man killed in 2014, was described as a "petty criminal" (Dukes and Gaither 2017).

Third, the effects of racial/ethnic differences in news portrayals on perceptions of crime and culpability has been examined (Altheide 1997; Dixon and Linz 2000a; Entman 1992; Entman and Rojecki 2000). For example, in an experimental setting that manipulated the degree of violence reported and the race of the perpetrator, Gilliam et al. (1996) found that "race works independently and in conjunction with racial stereotypes to influence people's concern about crime and their willingness to attribute criminal behavior to breakdowns in the African-American community" (p. 6). In an experimental setting that manipulated a news report about a fatal police shooting, researchers found that when stereotypes about African-Americans were included, such as having a criminal record, individuals placed less blame on the shooter (Dukes and Gaither 2017).

Several theories have been proposed to account for why there may be racial/ethnic 
disparities in the portrayal of individuals in the news. First, Dixon and Linz (2000b) argued that because of the dominance of White ownership of media outlets, Whites have the ability to "shape media content in a way that portrays their group favorably" (p. 548). News content may therefore reflect the stereotyping of out-group members who are non-White (Dixon and Linz 2000b). Another argument is that racism among those who produce the news is an unconscious form of everyday racism that manifests itself in racially-biased news reporting (Heider 2000). More recently, sociologists have argued that non-Whites are portrayed negatively in the news due to a complex combination of media power structures, market share competition driving coverage and portrayals, racial threat, and privileging White victims over non-White victims (Bjornstrom et al. 2010).

Lastly, researchers have argued that objective ideals for journalism have inadvertently led to ignorance, stereotyping, racist framing, and a reinforcement of the status quo (Mastin, Campo, and Frazer 2005; Shah and Thornton 2004; Squires 2007 2009). When civic unrest has sought to challenge the status quo, journalists have typically given credence to official authorities (Gitlin 2003; Reese 1990). Furthermore, it has been argued that "journalists have tended to highlight extreme positives and negatives for African-Americans and subject them to binaries such as hero (athlete) and villain (criminal), rather than investigate more complex causes of systematic bias" (Robinson and Culver 2016:3). Overall, this body of research suggests that crime news reports contain frames depicting racial/ethnic minorities less favorably than Whites. Reasons for this include racial disparities in media ownership, unconscious biases, market share competition, and pursuit of objective ideals compounded by a lack of understanding of systemic bias against racial and ethnic minorities. 
News portrayals of individuals with mental illness have also been examined in research. Despite mental illness being a common feature of everyday life, with approximately one in five Americans experiencing a mental health disorder in any given year (Insel 2015), news reports about persons with mental illness typically focus on rare and violent events (The Carter Center 2015). Fatal police shootings involving persons with mental illness are an example of such. Persons with mental illness are commonly portrayed in the media as violent criminals (Corrigan et al. 2005; Olstead 2002; Wahl 2003), or as "helpless, disempowered and child-like" (Olstead 2002:634). Importantly, how individuals with mental illness are portrayed in the media has ramifications for perceptions of mental illness. For example, research that has used an experimental research design has indicated that exposure to news reports associating violence with mental illness influences individuals to perceive people with mental illness as being dangerous (Dietrich, Heider, and Angermeyer 2006; Thornton and Wahl 1996).

As discussed in the introduction, it is currently not known how (or whether) stereotypes and stigma about mental illness are applied differentially by race/ethnicity in the news. However, it has been established in previous research that individuals with mental illness are often stigmatized in the news and that racial/ethnic minorities are portrayed less favorably in the news than Whites. An analysis of the media coverage surrounding fatal police shootings allows for an in-depth examination of news reports that contain discussions of both race/ethnicity and mental illness. Two hypotheses are tested in this article:

Hypothesis 1: The portrayal of individuals with mental illness killed by police in the news will differ by race/ethnicity.

Hypothesis 2: Non-whites with mental illness will be portrayed less favorably in the 
news than Whites with mental illness because the stigma and stereotypes associated with mental illness will intersect and reinforce racial/ethnic prejudices.

\section{Data and methods}

This article uses data published by The Washington Post in conjunction with online news reports collected by the author. The Washington Post data includes incidences from January 1, 2015 through December 31, 2016 in which a police officer in the United States, in the line of duty, fatally shot a civilian (Fuller et al. 2015). Data was gathered by examining news reports, investigative journalism, and examining police records obtained by open records requests (Fuller et al. 2015). The data includes information on both the race/ethnicity and the mental health status of individuals

killed by police. Individuals for whom this information was missing were excluded from analysis.

Information regarding every encounter recorded by the The Washington Post was checked for accuracy by the author against online news reports and following this process some amendments to the data were made. For example, two individuals were included in the original data but should not have been because they were killed by off-duty police officers. These cases were removed from analysis because there may be differences in how individuals were portrayed in the news if their death cannot be as directly associated with a police department, and instead with an off-duty police officer. In another case, an individual was recorded as not having mental illness by The Washington Post, but online news reports indicated otherwise so the author amended this case.

Using The Washington Post data to identify individuals with mental illness killed 
by police, the author used Google to search for online news reports about their death using their name and the location of the incident, followed by terms such as "police," "shooting," and "killed." Individuals were excluded from the sample if the only information available about their death was from law enforcement press releases or blog posts. This resulted in 301 individuals about whom news reports could be gathered. Of these 301 individuals, 54 were African-American, 39 were Hispanic, and 208 were White.

Whether an online news report contained information on how police contact was initiated was used as the criterion for selecting news reports. This criterion was chosen because it filtered out less detailed news reports. Using this criterion, one news report was collected at random for each individual killed by police to allow for a rich examination of the text. The use of LexisNexis to find news reports was not appropriate because after careful cross-checking of the results gleaned from the Google search versus the LexisNexis search it was revealed that LexisNexis had far fewer local news network sources, which tended to contain the most information about an incident. This purposive sampling strategy yielded news reports that are "information-rich" (Patton 2002:230). Patton (2002) argued that: "information-rich cases are those from which one can learn a great deal about issues of central importance to the purpose of the inquiry, thus the term purposeful sampling" (p. 230). Articles ranged from 174 words to 13,320 words, with an average of 1,176 words and a median of 948 words.

Table 1 displays frequencies of the types of news source analyzed by race/ethnicity. For coding purposes, national news outlets are defined as tabloid and broadsheet newspapers that have a national circulation, or national network news outlets that publish online news reports. Regional news outlets are defined as tabloid and 
broadsheet newspapers that serve a large regional area or major city. Local news outlets are defined as network affiliates operating at a local level that publish online news reports, local newspapers, or local news websites that journalists contribute to but that do not print news. One news report was published in the United Kingdom and one news report was published in Canada. Often, the most detailed news report about the incident was published by a local news outlet - 238 of the 301 news reports were published by local news outlets. Intuitively, this is not surprising. Regional or national news outlets have more competition among potential events to report on than local news outlets do. While police shootings are often not criminal homicides, research has found that in cities with few murders, local media provides more detailed coverage than media outlets in larger cities (Chermak 1994). Detailed news reports about Whites killed by police were most likely to be from local sources (81\%) compared to (77\%) of news reports about Hispanics and (74\%) of news reports about African-Americans. This may mirror the national interest in the killing of African-Americans by police, as news that is perceived to merit regional or national news coverage.

[Table 1 here]

News reports were downloaded and saved in portable document format (pdf) and imported into NVivo qualitative data analysis software. Segments of text were identified as fitting with one or multiple categories (in other words, coded) using a coding scheme created by the author (see Table 2). Segments of coded text were then compiled under the broader categories of 'victim' or 'villain'.

[Table 2 here] 


\section{Findings}

This findings section will examine the types of frames identified in the analyzed news reports and examples will be provided. Then, racial/ethnic differences in the use of frames in news reports will be examined to test both Hypothesis 1 (the portrayal of individuals with mental illness killed by police in the news will differ by race/ethnicity) and Hypothesis 2 (non-whites with mental illness will be portrayed less favorably than Whites with mental illness in the news because the stigma and stereotypes associated with mental illness will intersect and reinforce racial prejudices.)

\section{'Victim' frames}

Consistent with research on crime news, frames were used to portray individuals killed by police as 'victims' or 'villains.' The first type of victim frame that emerged from analysis was the victim of mental illness - an individual portrayed as being a victim of their own mental illness through discussion of mental illness.

Victims of mental illness. Consistent with research on the portrayal of mental illness in the news, common themes within the victim of mental illness frame were the concepts of suffering and loss of personal control. In a common reference to suffering, a family member stated: "he suffered with this mental disorder every day" (Hatfield 2016). In another example, a relative stated: "he was just swallowed by something he couldn't overcome" (Bernstein 2015). A quoted family member described a relative as being victim to their own mental illness which held them "hostage": "he was his own hostage" (Romero 2015).

Another frame present in the analyzed news reports was the idea that the death of the person with mental illness may be attributed to a lack of mental health services, 
and blame is placed on the health care system. For example, a family member described how her husband attempted to get treatment: "they turned him away. They told him there was no room, and that he'd have to make an appointment... I think the system failed him" (CBS 5 2015). Another example from a family member described how the assessment of mental illness in the "system" was a failure, rather than patient capacity, as the previous quote indicated: "we tried to get him mental help numerous times, but the system failed him, because he was declared 'sane.' He was very delusional. It was very obvious" (Chuck 2015).

Individuals killed by police were also portrayed as being victims of mental illness through a lack of police training. In one example, a family member stated: "due either to their poor training or their lack of qualifications to be police officers licensed to use deadly force to kill, the shots fired that day were unnecessary" (Parra, Duvernay, and Reyes 2016). The following quote from one of the analyzed news reports is from a public safety director who described the strain on police services: "while our officers have received training in this area [mental illness], more training, funding and care facilities across the entire health care and criminal justice spectrum are needed" (Smith 2016).

Another theme that emerged from analysis was that some individuals were portrayed as victims of mental illness through the long-term effects of their military experience. A news report described the situation for one individual killed by police: "he was a Vietnam Veteran. Friends and family say [he] was forced to take medication daily after he had returned from the war" (Lex 18 News 2015). In another example an individual is described as having "suffered from Post-Traumatic Stress Disorder from his time serving in the Navy" (Hanson 2015). 
Victims of police actions. The second type of 'victim' frame occurred when an individual was portrayed as a victim of police actions. This frame was constructed through the inclusion of questioning police actions and references to protests.

References to protests arguably invoke a sense of injustice as a reaction to the actions of police. The inclusion of discussion about protests helps create narratives about the innocence of the person killed by police. Some of these references were regarding specific protests as a result of the particular individual dying. For example, it was reported that "dozens of people gathered Sunday night in Pershing Square to protest the shooting" (Holland et al. 2015). Other examples associated the homicide with other protests around the country. For example, a news report quoted a family member who described the death of her sibling: "[she] said the shooting immediately made her think of a series of police involved killings that have happened across the country recently, prompting protests and federal inquiries. 'It's just crazy... I think police officers are too trigger-happy lately'" (The Enterprise 2015).

Quotes from community members, family members, and organizations questioning or criticizing police contributed to the overall frame regarding these individuals being victims of police actions. These quotes were often emotive and centered on being fearful of calling the police, questioning police actions, and discussing the need for police accountability. For example, a community member stated: "now you are scared to call police if you see anything because you don’t know what police are going to do. They have license to kill people for no reason and that is scary" (Rush 2015). Another community member questioned why police would fatally shoot an individual without a gun: "he didn't have a gun in his hand, but they [police] put bullets in him and then hit him with a shotgun. Come on now... We have to hold them accountable" (Esquivel 
2016).

Quotes from family members tended to be particularly emotive. For example, a relative stated: "they didn't have to shoot him like the way they killed him: like a... dog" (Crimaldi 2015). Quotes from family members also centered on the idea that their relatives were not deserving of being killed by police. For example, one family member stated: "I felt helpless... He didn't deserve to die the way he did" (Khalil 2017).

\section{'Villain' frames}

In contrast to these victim frames, frames relating to substance use, criminal record, references to an individual being a 'suspect', violent or threatening behavior, and support for police create an overall impression that the individual killed by police was a culpable 'villain'. Their death may be regarded as inevitable, or even deserving. For example, a family member stated: "this was the type of behavior that was inevitable to happen with the drug abuse and violence and everything that's happened" (Lipscomb 2015). Referring to a different individual killed by police, a relative stated: "it wasn't the officers' fault... This was his dumb mistake" (Remer 2016).

References to an individual's criminal record may present the individual as villainous and by discussing a criminal record in the news report, narratives about excessive police use of force are subtly undermined. A city mayor is quoted as remarking: "our guys [police] are going after bad guys" (Butts 2016). In another example, a journalist described how "the officer recognized the man as a 'troublesome criminal' " (Fox 2 2015), and a police officer described his thoughts before fatally shooting an individual: "what crossed my mind was finding the bad guy" (McCoy et al. 2016). Characterizing an individual as inherently 'bad' reinforces distinctions between 
'good' and 'bad'; victims of police actions versus villains.

The inclusion of discussion about an individual's violent or threatening behavior prior to being fatally shot by police frames the event within the context of attributing responsibility to the individual killed by police. Often, these descriptions were dramatic. For example, a journalist described an individual fatally shot by police as "swinging the knives wildly as he was shot" (Treen 2016). In another example, the events preceding the death of an individual are described by a police officer as "a very intense situation and a brutal, brutal fight" (Holland et al. 2015). Furthermore, at times descriptions implied an association between mental illness and violence. For example, "Tarboro shooter had been treated for mental issues" (Swain 2015) and "Armed suspect shot by Jacksonville police had been suicidal, wanted to go out 'Waco-style'" (Treen 2016).

While substance use disorders are widely considered to be a mental illness within the medical profession, discussions of substance use disorders may portray the individual as having poor character because of the associated stigma. Choosing to discuss substance use disorders implies that their substance use makes them culpable for the actions of police. For example, a journalist described how a family member "said his sister had lived a troubled life, which led to drug addiction and dozens of nonviolent encounters with law enforcement" (Sernoffsky and Ho 2015). In another example, the individual killed reportedly had a "history" of substance use, implying that this history had some bearing on their death and casting doubt over the character of the individual: "family members told investigators that [he] also had a history of alcohol and meth use" (Kronebusch 2016).

Expressed support of police actions by community members, family, and the media 
suggest that the individual killed by police was the 'villain,' while police are the 'heroes.' One example from a quoted community member highlights the humanity in police making mistakes: "I thought I'd come and say a prayer...a prayer of peace because these are peace officers and sometimes we forget, we forget we're not perfect" (Bolton 2016). An individual described as a "family friend" stated: "I don't blame that trooper at all, and none of the family blames him in anyway... I actually feel very bad for the trooper and his family because he has to live with this for the rest of his life" (9 \& 10 News 2016). In another example, a family member also expressed support for police: "I actually applaud them for doing what they had to do to protect their own" (Rasta 2015). A journalist also subtly expressed support for police in a description of how the fatal shooting of an individual appeared to distress a police officer: "although both officers say that they're OK, Collins appears shaken by the incident, at one point throwing a glove on the ground. At another point, he is bent at the waist with his hands on his thighs" (Cassidy 2015).

How the individual killed by police is described carries social connotations and implications for thinking about personal responsibility and may be regarded as a form of labeling. Labeling may be defined as "the assigning of social significance to particular characteristics" (Link et al. 2004:516). Often, individuals with mental illness killed by police were described as a "suspect," a term that has criminal connotations. Examples included "a drug suspect" (Rogers 2015) and a "violent suspect" (Hudson 2015). A journalist also described an individual as a "suicidal suspect" (Ann 2016), implicitly associating suicidal ideation with criminality. 


\section{Characteristics of news frames by race/ethnicity}

This part of the results section presents information on racial/ethnic differences in the types of frames used in the analyzed news reports. Table 3 displays information on the percentage of content that was coded for each news report that is attributable to each type of frame by race/ethnicity. Frame frequencies are displayed in parentheses. The results are consistent with Hypothesis 1 (the portrayal of individuals with mental illness killed by police in the news will differ by race/ethnicity.)

However, the results are not wholly consistent with Hypothesis 2 (non-whites with mental illness will be portrayed less favorably than Whites with mental illness in the news because the stigma and stereotypes associated with mental illness will intersect and reinforce racial prejudices.) The intersection of race/ethnicity and mental illness in the analyzed news reports is complex. Whites were most likely to be portrayed as victims of mental illness, by being described as 'sufferers' of mental illness, describing a lack of mental health services, a lack of police training regarding interacting with persons who have mental illness, and the role of military service in developing mental illness. However, this is juxtaposed against frames that portrayed them as violent. African-Americans were most likely to be portrayed as victims of police actions, through descriptions of protests and the questioning of police actions. However, they were also most likely to be described negatively as a "suspect." Hispanics were most likely to be portrayed as 'villains' through discussions of criminal records, substance or alcohol use, and support for police.

Table 4 displays the results of collating frames present in the news reports according to whether overall they portrayed an individual killed by police as a 'villain' or a 'victim.' In the table, the percentage of content that was coded for each news 
report that is attributable to each type of frame by race/ethnicity is displayed. Frame frequencies are displayed in parentheses. Overall, Whites with mental illness killed by police were most likely to be portrayed as victims of their own mental illness, while African-Americans were most likely to be portrayed as victims of police actions and Hispanics were most likely to be portrayed as villains.

[Tables 3 and 4 here]

\section{Discussion and conclusion}

News coverage about the fatal shooting of individuals by police is used in this article as a case study to examine how attributes of mental illness may be differentially applied by race/ethnicity to either positively or negatively portray individuals. This article presents two important findings. First, there are racial/ethnic differences in how individuals with mental illness killed by police are portrayed in the news. Second, non-Whites are not portrayed in the same manner when race/ethnicity and mental illness intersect, with Hispanics being portrayed less favorably than African-Americans.

Why do the portrayals appear as they do? Why, as non-Whites, are Hispanics portrayed less favorably, but African-Americans are not portrayed less favorably? One could argue that the negative portrayal of Hispanics with mental illness killed by police simply reflects reality. However, an analysis of data published by The Washington Post indicates otherwise. Specifically, Hispanic individuals included in this article analysis were actually the least likely of the racial/ethnic groups included in this analysis to have been attacking police at the time of their death. Of the Hispanics included in this analysis, $46 \%$ were recorded as attacking police at the time of their death, compared to $52 \%$ of African-Americans and $68 \%$ of Whites. Hispanics were also less likely than 
Whites to have a projectile weapon such as a gun - $49 \%$ of Hispanics were reported by The Washington Post to have had this type of weapon when they died, slightly less than African-Americans with mental illness killed by police (52\%) and much less than Whites (68\%). Although these are crude indicators, they suggest that portrayals of Hispanics with mental illness killed by police that support police may not be merited. However, perhaps Whites killed by police were portrayed accurately, at least with regard to violence, because they were most likely to be recorded by The Washington Post as attacking police at the time of the death and they were also most likely to have a projectile weapon such as a gun.

For African-Americans with mental illness killed by police, the racial/ethnic differences in the use frames discovered in this article are arguably an example of journalism being an "an active, interpretive cultural activity" (Ward 2010:146). Robinson and Culver (2016) argued that this does not mean that journalism should be opinionated, but rather that it should include "diverse perspectives...interpretive reporting argues that journalists make sense of communities along with the people who inhabit them" (p. 2). In this context, journalists may be endeavoring to make sense of these incidents within the context of African-American communities. Furthermore, these news reports do not reinforce the status quo which is at odds with existing research on the portrayal of minorities in news (Mastin, Campo, and Frazer 2005; Shah and Thornton 2004; Squires 2007 2009), or give credence to official authorities (Gitlin 2003; Reese 1990), in this instance, police. Rather, they privilege community members who question police actions and decisions, and they highlight protests as a form of counter-movement against the actions of police. Other recently published research also suggests that, specifically in the context of fatal police shootings of African-American 
men, traditional paradigms of news reporting that give credence to official authorities "may be breaking down" by being critical of police practices and being attentive to systemic causes of police misconduct (Lee, Weitzer, and Martinez 2018:216).

It is unclear whether the framing of individuals with mental illness killed by police in news reports contributes to stereotypes associated with mental illness, such as being violent or being a helpless sufferer, being differentially perceived by race/ethnicity. The author does not assume that those who are exposed to online news reports about individuals with mental illness killed by police are passive recipients of the racial/ethnic differences in media coverage. Furthermore, many readers are likely to be unaware of differences in the frames used in these news reports. However, racial/ethnic differences in the portrayal of individuals with mental illness killed by police have been established in this article and more research should be done to examine the effects of such differences.

The findings of this article point toward more research being needed that utilizes an intersectional approach. In particular, future research may wish to examine how individuals with identities at the intersection of race/ethnicity and mental illness are portrayed in crime news that focuses on events other than the fatal shootings of civilians by police, or news that is not about crime at all. News reports about persons with mental illness often focus on rare, violent events (The Carter Center 2015), as the news reports examined in this article do. However, researchers should endeavor to examine other types of news coverage where potential racial/ethnic differences in the news portrayals of individuals with mental illness may occur. Intersectionality is an important, yet arguably underutilized, tool in understanding how individuals with mental illness are differentially portrayed in the news by race/ethnicity. 


\section{References}

9 \& 10 News. 2015. "MSP Investigates Deadly Trooper-Involved Shooting in Mackinac County." $9 \& 10$ News. Retrieved March 15, 2017

(http://www.9and10news.com/story/33326016/msp-investigates-deadly-trooperinvolved-shooting-in-mackinac-county)

Altheide, David L. 1997. "The News Media, the Problem Frame, and the Production of Fear." Sociological Quarterly 38:647-68.

Ann, Ashley. 2016. "Virginia State Police Identify Man Fatally Shot by Officer." $A B C$ 13. Retrieved March 23, 2017 (http://wset.com/news/local/virginia-state-policeinvestigating-fatal-officer-involved-shooting-in-buchanan-county)

Bernstein, Maxine. 2015. "Man Killed by Portland Police 'was Just Swallowed' by Bipolar Disorder, Mother Says." The Oregonian/Oregon Live.

Retrieved March 15, 2017

(http://www.oregonlive.com/portland/index.ssf/2015/11/man_killed_by_portland_police.html)

Bjornstrom, Eileen E. S., Robert L. Kaufman, Ruth D. Peterson, and Michael D.

Slater. 2010. "Race and Ethnic Representations of Lawbreakers and Victims in

Crime News: A National Study of Television Coverage." Social Problems 57(2): 269-293.

Bolton, Tim. 2016. "Suicidal Man Armed with Knife Fatally Shot by Police in Santa Maria." Noozhawk. Retrieved March 17, 2017

(https://www.noozhawk.com/article/man_armed_with_knife_reportedly_shot_by_police _in_santa_maria)

Butts, Rebecca. 2016. "Police: Man Pointed BB Gun before Officers Shot." Cincinnati.com. Retrieved March 18, 2017 
(http://www.cincinnati.com/story/news/2016/01/11/armed-robbery-suspect-shotkilled-officer/78663536)

Cassidy, Maggie. 2015. "State Releases Video of Fatal Shooting by Haverhill Officers." Valley News. Retrieved March 15, 2017

(http://www.vnews.com/Archives/2015/09/HaverhillVideos-mec-vn-092615)

Cavender, Gary and Aogan Mulcahy. 1998. "Trial by Fire: Media Constructions of Corporate Deviance." Justice Quarterly 15(4):697-717,

Chermak, Steven M. 1994. "Body Count News: How Crime is Presented in the News Media." Justice Quarterly 11:561-82.

Chiricos, Theodore and Sarah Eschholz. 2002. "The Racial and Ethnic Typification of Crime and The Criminal Typification of Race and Ethnicity in Local Television News." Journal of Research in Crime and Delinquency 39(4):400-20.

Chuck, Elizabeth. 2015. "Dallas Police Attack: Suspect James Boulware 'Heard Voices,' Mom Says." NBC News. Retrieved March 23, 2017 (http://www.nbcnews.com/news/us-news/suspect-dallas-police-ambush-had-historyviolence-n374921)

Corrigan, Patrick W., Amy C. Watson, Gabriela Gracia, Natalie Slopen, Kenneth Rasinski, and Laura L. Hall. 2005. "Newspaper Stories as Measures of Structural Stigma." Psychiatric Services 56:551-556.

Crenshaw, Kimberlé. 1989. "Demarginalizing the Intersection of Race and Sex: A Black Feminist Critique of Antidiscrimination Doctrine, Feminist Theory and Antiracist Politics." University of Chicago Legal Forum 1:139-167.

Crenshaw, Kimberlé. 2015. "Why Intersectionality Can’t Wait." The Washington Post Retrieved June 5, 2018 (https://www.washingtonpost.com/news/in-theory/ 
wp/2015/09/24/why-intersectionality-cant-wait/?utm_term=.a2ce08b6ba41)

Crimaldi, Laura. 2015. "Man Fatally Shot Near BU Had Previous Run-ins with

Police.” Boston Globe. Retrieved March 15, 2017 (https://www.bostonglobe.com /metro/2015/06/20/shooting/ouq XSoWWyL45tR8DV7fl4N/story.html)

Dixon, Travis L. 2007. "Black Criminals and White Officers: The Effects of Racially Misrepresenting Law Breakers and Law Defenders on Television News." Media Psychology 10(2):270-291.

Dixon, Travis L. 2015. "Good Guys are Still Always in White? Positive Change and Continued Misrepresentation of Race and Crime on Local Television News." Communication Research 44(6):775-792.

Dixon, Travis L. and Daniel Linz. 2000a. "Overrepresentation and Underrepresentation of African Americans and Latinos as Lawbreakers on Television News." Journal of Communication 50(2):131-154.

Dixon, Travis L. and Daniel Linz. 2000b. "Race and the Misrepresentation of Victimization on Local Television News" Communication Research 27(5):547-573.

Dixon, Travis L. and Keith B. Maddox. 2006. "Skin Tone, Crime News, and Social Reality Judgments: Priming the Stereotype of the Dark and Dangerous Black Criminal." Journal of Applied Social Psychology 35(8):1555-1570.

Dukes, Kristin Nicole and Gaither, Sarah E. 2017. "Black Racial Stereotypes and Victim Blaming: Implications for Media Coverage and Criminal Proceedings in Cases of Police Violence against Racial and Ethnic Minorities." Journal of Social Issues 73(4):789-807.

Entman, Robert M. 1992. "Blacks in the News: Television, Modern Racism, and Cultural Change." Journalism Quarterly 69:341-361. 
Entman, Robert M. and Andrew Rojecki. 2000. The Black Image in the White Mind: Media and Race in America. Chicago, IL: University of Chicago Press.

Esquivel, Paloma. 2016. "Shooting of Unarmed White Teenager has Racially Diverse Fresno Trying to Make Sense of Black Lives Matter." Los Angeles Times. Retrieved March 14, 2017 (http://www.latimes.com/local/lanow/la-me-ln-fresno-shooting20160721-snap-story.html)

Fox 2. 2015. "Police: Unarmed Suspect Fatally Shot by Officer in Struggle for Gun." Fox 2. Retrieved March 15, 2017 (http://www.fox2detroit.com/news/local-news/61023770-story)

Fuller, Doris A., H. Richard Lamb, Michael Biasotti, and John Snook. 2015. Overlooked in the Undercounted: The Role of Mental Illness in Fatal Law Enforcement Encounters. Retrieved November 12, 2016 (http://www.treatment advocacycenter.org/storage/documents/overlooked-in-the-undercounted.pdf)

Garfinkel, Harold. 1956. "Conditions of Successful Degradation Ceremonies." American Journal of Sociology 61:420-424.

Gilliam, Franklin D. , Shanto Iyengar, Adam Simon, and Oliver Wright. 1996. "Crime in Black and White: The Violent, Scary World of Local News. The International Journal of Press/Politics 1:6-23.

Gitlin, Todd. 2003. The Whole World is Watching: Mass Media in the Making and Unmaking of the New Left. Berkeley, CA: University of California Press.

Goldsmith, Andrew. 2010. "Policing's New Visibility." British Journal of Criminology, 50:914-934.

Hanson, Blake. 2015. "Police: Veteran Shot, Killed by Officers After Firing Weapon." WSOC-TV. Retrieved March 15, 2017 (http://www.wsoctv.com/news/local/heavy- 
police-presence-after-gastonia-shooting/52170205)

Hatfield, Mycah. 2016. "Update: Family of Victim in Officer-involved Shooting in New Iberia Speaks." KATC 3. Retrieved March 23, 2017

(http://www.katc.com/story/32365959/family-of-man-killed-by-iberia-parishdeputy-believes-death-could-have-been-prevented)

Heider, Don. 2000. White News: Why Local News Programs Don't Cover People of Color Mahwah, NJ: Lawrence Erlbaum.

Holland, Gale, Kate Mather, Sarah Parvini and Richard Winton. 2015. "Man went for Gun During 'Brutal' Skid Row Struggle, LAPD Chief Says.” Los Angeles Times. Retrieved March 14, 2017 (http://www.latimes.com/local/california/la-me-lapdshooting-20150302-story.html\#page=1)

Hudson, Jerry A. 2015. "Douglas Now Obtains 911 Audio of Officer-Involved Shooting." Douglas Now. Retrieved March 23, 2017 (http://douglasnow.com/index.php/news/item/1003-douglas-now-obtains-911audio-of-officer-involved-shooting)

Insel, Thomas. 2015. "Mental Health Awareness Month: By the Numbers." Retrieved March 14, 2017 (https://www.nimh.nih.gov/about/directors/thomasinsel/blog/2015/mental-health-awareness-month-by-the-numbers.shtml)

Khalil, Joe. 2017. "Police Footage of Dazion Flenaugh Shooting Leaves Family Feeling 'Helpless'." Fox 40. Retrieved March 21, 2017 (http://fox40.com/2017/01/13/police-footage-of-dazion-flenaugh-shooting-leavesfamily-feeling-helpless)

Kronebusch, Lauren. 2016. "Report Clears Cops in Fatal Shooting." The Daily News. Retrieved March 23, 2017 (ttp://tdn.com/news/report-clears-cops-in-fatal- 
shooting/article_c19a908b-1ab2-599f-8e22-935a61814ba0.html)

Lee, Angela S., Ronald Weitzer, and Daniel E. Martinez. 2018. "Recent Police Killings in the United States: A Three-City Comparison." Police Quarterly 21(2): 196-222.

Lex 18 News. 2015. "Magoffin Co. Man Shot By Trooper." Lex 18 News.

Retrieved March 23, 2017 (http://www.lex18.com/story/27884078/ magoffin-coman-dies-after-police-standoff)

Link, Bruce G., Lawrence H. Yang, Jo C. Phelan, and Pamela Y. Collins. 2004.

"Measuring Mental Illness Stigma." Schizophrenia Bulletin 30(3):511-541.

Lipscomb, Jessica. 2015. "Woman Dies after Chase, Gunfire Exchange with Collier Deputies." Naples Daily News. Retrieved March 23, 2017

(http://archive.naplesnews.com/news/crime/woman-dies-after-chase-gunfireexchange-with-collier-deputies-ep-1320771152-340322001.html)

Mastin, Teresa, Shelly Campo, and M. Somjen Frazer. 2005. "In Black and White: Coverage of U.S. Slave Reparations by the Mainstream and Black Press." Howard Journal of Communications 16(3):201-223.

McCombs, Maxwell. 1997. "Building Consensus: The News Media's Agenda-Setting Roles." Political Communication 14:433-43.

McCombs, Maxwell E. and Donald L. Shaw. 1993. "The Evolution of Agenda-Setting Research: Twenty-five Years in the Marketplace of Ideas." Journal of Communication 43:58-67.

McCoy, Blake, Alexander Smith, Andrew Rudansky, Erin Calabrese, and Alex Johnson. 2016. "Cedric Larry Ford Kills 3, Injures 14 in Kansas Shooting Spree.” NBC News. Retrieved March 14, 2017 (http://www.nbcnews.com/news/us-news/cedric-larryford-kills-3-injures-14-kansas-shooting-spree-n526316) 
Olstead, Riley. 2002. "Contesting the Text: Canadian Media Depictions of the Conflation of Mental Illness and Criminality." Sociology of Health 8 Illness 24(5):621-643.

Paletz David L. and Robert M. Entman. 1981. Media, Power, Politics. New York, NY: Free Press.

Parra, Esteban, Adam Duvernay and Jessica Masulli Reyes. 2016. "McDole Shooting: Wilmington Police Won’t be Charged." The News Journal. Retrieved March 17, 2017 (http://www.delawareonline.com/story/news/local/2016/05/12/delaware-copswont-charged-jeremy-mcdole-shooting/84245736)

Patton, Michael Q. 2002. Qualitative Research ES Evaluation Methods. Thousand Oaks, CA: Sage Publications.

Rasta, Anoushah. 2015. "Driver Shot, Killed after Wild Police Chase Across SW Houston." Click 2 Houston. Retrieved March 13, 2017 (http://www.click2houston. com/news/texas/driver-shot-killed-after-wild-police-chase-across-sw-houston)

Remer, Jessica. 2016. "Police Release Dashcam Video of Officer-Involved Shooting of Man with Axe." ABC 8. Retrieved March 17, 2017 (http://ktul.com/news /local/police-release-dashcam-video-of-officer-involved-shooting-of-man-with-ax) Reese, Stephen D. 1990. "The News Paradigm and the Ideology of Objectivity: A Socialist at the Wall Street Journal." Critical Studies in Mass Communication $7: 390-401$.

Robinson, Sue and Kathleen Bartzen Culver. 2016. "When White Reporters Cover Race: News Media, Objectivity and Community (Dis)trust." Journalism:1-17. Rogers, Catherine. 2015. "Portsmouth Asks State Police to Investigate Fatal Shooting by Officer." WAVY-TV. Retrieved March 23, 2017 
(http://wavy.com/2015/03/25/portsmouth-asks-state-police-to-investigate-fatalshooting-by-officer)

Romero, McKenzie. 2015. "Family of Man Killed by Spanish Fork Police Say They Had No Options to Save Him.” Deseret News. Retrieved March 14, 2017 (http://www.deseretnews.com/article/865635716/Family-of-man-killed-by-SpanishFork-police-say-they-had-no-options-to-save-him.html?pg=all)

Rush, Tyree. 2015. "Naked Man Shot, Killed by Police." CBS 46. Retrieved March 16, 2017 (http://www.cbs46.com/story/28301956/naked-man-shot-by-police-officerat-dekalb-county-apartments)

Scheufele, Dietram A. 2000. "Agenda-Setting, Priming, and Framing Revisited: Another Look at Cognitive Effects of Political Communication." Mass Communication $\mathscr{E}$ Society 3(2/3):297-316.

Sernoffsky, Evan and Vivian Ho. 2015. "Woman Shot Dead by S.F. Cops Was 'Lost' to Street Life." SF GATE. Retrieved March 17, 2017 (http://www.sfgate.com /news/article/Driver-killed-by-S-F-police-identified-as-6142564.php)

Shah, Hemant and Michael Charles Thornton. 2004. Newspaper Coverage of Interethnic Conflict: Competing Visions of America. Thousand Oaks, CA: SAGE. Smith, Kelly. 2016. "No Charges for Officer in Plymouth Police Shooting that Killed Man in a Mental Health Crisis." Star Tribune. Retrieved March 12, 2017 (http://www.startribune.com/no-charges-for-officer-in-plymouth-police-shootingthat-killed-man-in-a-mental-health-crisis/382259251)

Squires Catherine R. 2007. Dispatches from the Color Line: The Press and Multiracial America. Albany, NY: State University of New York Press.

Squires, Catherine R. 2009. African Americans and the Media. Malden, MA: Polity. 
Swain, Carly. 2015. "Police: Tarboro Shooter had been Treated for Mental Issues."

WITN. Retrieved March 23, 2017 (http://www.witn.com/home/headlines/Shootingat-Tarboro-barbershop-under-investigation-294513821.html)

The Carter Center. 2015. Journalism Resource Guide on Behavioral Health. Retrieved January 12, 2017 (https://www.cartercenter.org/resources/pdfs/health/mental health/2015-journalism-resource-guide-on-behavioral-health.pdf)

The Enterprise. 2015. "Family Decries Fatal Brockton Police Shooting." The Enterprise. Retrieved March 21, 2017 (http://www.enterprisenews.com/article/20150702/NEWS/150708999)

Thornton, JoAnn A. and Otto F. Wahl. 1996. "Impact of a Newspaper Article on Attitudes Toward Mental Illness." Journal of Community Psychology 24(1):17-25.

Treen, Dana. 2016. "Knife-Wielding 19-Year-Old Orange Park Man Shot after Charging Jacksonville Police has Died." The Florida Times-Union, Retrieved March 18, 2017 (http://jacksonville.com/news/crime/2016-05-16/story/knife-wielding-19year-old-orange-park-man-shot-after-charging)

Wahl, Otto F. 2003. "News Media Portrayal of Mental Illness: Implications for Public Policy." American Behavioral Scientist 46:1594-1600.

Ward, Stephen J. 2010. "Inventing Objectivity: New philosophical Foundations." Pp. 137-152 in Journalism Ethics: A Philosophical Approach, edited by C. Meyers. New York, NY: Oxford University Press.

The Washington Post. 2017. "Police Shootings 2017 Database." The Washington Post Retrieved January 17, 2018 (https://www.washingtonpost.com/graphics/national/police-shootings-2017) 


\section{Appendix: Tables}

Table 1. Frequencies of Types of News Source Analyzed by Race/Ethnicity

\begin{tabular}{lccc}
\hline & \multicolumn{3}{c}{ Race/Ethnicity } \\
\cline { 2 - 4 } Type of News Outlet & African-American & White & Hispanic \\
\hline International Network $(n=1)$ & 1 & 1 & 0 \\
International Tabloid $(n=1)$ & 3 & 0 & 0 \\
National Newspaper $(n=12)$ & 5 & 4 & 5 \\
National Network $(n=8)$ & 0 & 3 & 0 \\
National Tabloid $(n=3)$ & 3 & 2 & 1 \\
Regional Newspaper $(n=33)$ & 2 & 28 & 2 \\
Regional Tabloid $(n=5)$ & 12 & 2 & 1 \\
Local Newspaper $(n=80)$ & 25 & 58 & 10 \\
Local Network $(n=133)$ & 3 & 90 & 18 \\
Local News Website $(n=25)$ & 54 & 20 & 2 \\
\hline Total $N=301$ & & 208 & 39 \\
\hline
\end{tabular}

Table 2. Coding Scheme and Definitions

\begin{tabular}{ll}
\hline Code Name & Definition \\
\hline Victim of Mental Illness & $\begin{array}{l}\text { Any mention of diagnosis, symptoms, treatment, services, suicide, } \\
\text { and the following in relation to mental illness: being a'sufferer', } \\
\text { being a veteran, police training, mental illness statistics }\end{array}$ \\
$\begin{array}{l}\text { Victim of Police Actions } \\
\text { Protests }\end{array}$ & $\begin{array}{l}\text { Any mention of protests against police actions } \\
\text { Question Police Actions }\end{array}$ \\
$\begin{array}{l}\text { Any mention of questioning police actions, being fearful of calling } \\
\text { the police, and discussing the need for police accountability }\end{array}$ \\
$\begin{array}{l}\text { Villain } \\
\text { Criminal Record }\end{array}$ \\
$\begin{array}{l}\text { Any mention of criminal record } \\
\text { Anypport for Police }\end{array}$ \\
$\begin{array}{l}\text { Suspect } \\
\text { Violence by Person Killed }\end{array}$ & $\begin{array}{l}\text { Any mention of illegal substance use or alcohol } \\
\text { Any mention of the individual killed behaving in a violent manner }\end{array}$ \\
\hline
\end{tabular}


Table 3. Percentage and Frequency of Frames by Race/Ethnicity

\begin{tabular}{lccc}
\hline & \multicolumn{3}{c}{ Race/Ethnicity } \\
\cline { 2 - 4 } \multicolumn{1}{l}{ Name of Frame } & African-American & White & Hispanic \\
\hline Victim of Mental Illness & $24 \%(80)$ & $29 \%(338)$ & $21 \%(32)$ \\
$\quad$ Mental Illness & & \\
& & & \\
Victim of Police Actions & $4 \%(12)$ & $0.5 \%(6)$ & $2 \%(3)$ \\
$\quad$ Protests & $28 \%(92)$ & $6 \%(71)$ & $7 \%(11)$ \\
Question Police Actions & & & \\
& & & \\
Villain & $4 \%(14)$ & $9 \%(106)$ & $18 \%(27)$ \\
Criminal Record & $3(11)$ & $8 \%(93)$ & $9 \%(14)$ \\
Substance or Alcohol Use & $0.3 \%(1)$ & $2 \%(20)$ & $7 \%(10)$ \\
Support for Police & $12 \%(39)$ & $11 \%(123)$ & $10 \%(15)$ \\
Suspect & $25 \%(81)$ & $34 \%(397)$ & $26 \%(39)$ \\
Violence by Person Killed & $100.3 \%(330)$ & $99.5 \%(1154)$ & $100 \%(151)$ \\
\hline Total &
\end{tabular}

Notes

Chi-squared test for null hypothesis that there is no relationship between race/ethnicity and the frames used in the analyzed news reports. Chi-squared: 203.3963, degrees of freedom (14), $p<.001$. Percentages may not add to $100 \%$ because of rounding.

Table 4. Percentage and Frequency of Victim or Villain Frames by Race/Ethnicity

\begin{tabular}{lccc}
\hline & \multicolumn{3}{c}{ Race/Ethnicity } \\
\cline { 2 - 4 } Name of Frame & African-American & White & Hispanic \\
\hline Victim of Mental Illness & $24 \%(80)$ & $29 \%(338)$ & $21 \%(32)$ \\
Victim of Police Actions & $32 \%(104)$ & $7 \%(77)$ & $9 \%(14)$ \\
Villain & $44 \%(146)$ & $64 \%(739)$ & $70 \%(105)$ \\
\hline Total & $100 \%(330)$ & $100 \%(1154)$ & $100 \%(151)$ \\
\hline
\end{tabular}

Notes

Chi-squared test for null hypothesis that there is no relationship between race/ethnicity and the frames used in the analyzed news reports that portray individuals favorably or unfavorably. Chi-squared: 157.3977, degrees of freedom (4), $p<.001$. 